\title{
SEARCH STRATEGIES OF A PURSUIT-DIVING MARINE BIRD AND THE PERSISTENCE OF PREY PATCHES
}

\author{
Gail K. Davoren, ${ }^{1,3}$ William A. Montevecchi, ${ }^{1}$ And John T. Anderson ${ }^{2}$ \\ ${ }^{1}$ Biopsychology Programme, Departments of Biology and Psychology, Memorial University of Newfoundland, St. John's, \\ Newfoundland, Canada AlB $3 X 9$ \\ ${ }^{2}$ Northwest Atlantic Fisheries Centre, Fisheries and Oceans Canada, P.O. Box 5667, St. John's, \\ Newfoundland, Canada A1C $5 \times 1$
}

\begin{abstract}
We explored foraging strategies used by marine animals to search for prey by examining the relative importance of information exchange and memory in a cold ocean environment from 1998 to 2000. Recent technological advances have increased our knowledge of the foraging patterns of marine predators, but few of these studies have concurrently measured prey distribution and behavior. We quantified the arrival and departure behavior of a pursuit-diving, colonial seabird, the Common Murre, Uria aalge, at two colonies on the eastern Newfoundland Shelf through observational techniques. We also measured the distribution, abundance, and behavior of the capelin, Mallotus villosus, the main prey species of murres, within foraging ranges of each colony, using hydroacoustic, vessel-based techniques. Return and departure flight directions of murres did not match at either colony during the same period. This indicated that murres departing colonies did not use information on prey distributions outside of visual range of the colony provided by the flight paths of returning flocks of birds to the colony carrying fish. High-abundance aggregations of capelin were reliably found within specific $2.25-\mathrm{km}$ areas ("hot spots") for up to two weeks within the foraging ranges of murres from both colonies $(\sim 100 \mathrm{~km})$. This circumstance suggests that murres could use memory to locate hot spots on the coarse scale (1$100 \mathrm{~km}$ ) of foraging ranges from both colonies. Specific commuting routes (regular flight paths) of murres toward and away from hot spots were obvious at sea, and feeding murres consistently marked the location of capelin schools within hot spots. These distributions provided excellent conditions for murres to locate capelin schools on both coarse and fine (1-1000 m) scales by cueing to the activities of conspecifics, known as local enhancement. While central-place foraging from breeding colonies, murres likely use a mixture of memory and local enhancement to locate prey, depending on the spatial and temporal resolution of search and current prey conditions. Uncovering such behavioral mechanisms responsible for predator-prey interactions increases our understanding of linkages among trophic levels and, ultimately, ecosystem dynamics.
\end{abstract}

Key words: capelin; central place foraging; Common Murre; hot spot; information center hypothesis; information exchange; local enhancement; Mallotus villosus; memory; scale; search; Uria aalge.

\section{INTRODUCTION}

To exploit a resource, animals must know where it is located (Clark and Mangel 1984). Animals searching for food over a heterogeneous landscape must search on multiple spatial and temporal scales (Russell et al. 1992, Fauchald et al. 2000). The strategies used to locate mobile prey depend on the temporal rate at which the predator's foraging environment changes (Pyke 1984).

Animals provisioning offspring from a central place are physically separated from their foraging environment ("central place foragers," Orians and Pearson 1979). Therefore, they first must search for an area where food patches are likely to be found, or a foraging

Manuscript received 11 April 2002; revised 21 November 2002; accepted 23 November 2002; final version received 18 December 2002. Corresponding Editor: G. M. Henebry.

${ }^{3}$ E-mail: z73gkd@mun.ca habitat, and then for food patches within this habitat (Veit 1999). Travel time between the central place and food patches and the foraging time within patches once found both limit the amount of food that can be provided to offspring (Orians and Pearson 1979). Therefore, these are crucial constraints on reproductive performance (Clode 1993) and animals employ tactics that minimize the time spent searching and capturing prey.

To allow a more rapid location and exploitation of food patches from a central place, animals could use past experience or memory (Miliniski 1994, Mackney and Hughes 1995). Memory operates at multiple spatial and temporal scales, depending on the degree to which prey aggregations are persistent and the perceptual constraints of the predator. Individuals also can reduce the time spent searching by using information provided by other conspecifics (Ryer and Olla 1991, 1992). The "information center hypothesis" (ICH) postulates that information is exchanged among individuals at the cen- 
tral place, such as a colony or roost, about the location of food patches beyond the visual range of the central place (on a coarse scale of 1-100 km; Ward and Zahavi 1973, Haury et al. 1978). For instance, naïve animals may follow successful animals to prey aggregations (Ward and Zahavi 1973) or track the routes of animals returning to the central place (Gaston and Nettleship 1981, Burger 1997). Information also can be exchanged by cueing to the foraging activities of others within visual range of the central place, known as local enhancement (Wittenberger and Hunt 1985). Local enhancement also operates when searching for prey away from the central place but is restricted by the visual range of the predator (on a fine scale of 1-1000 m; Haury et al. 1978). The degree of information exchange reflects the balance between cooperative and competitive interactions among individuals at food patches (e.g., Irons 1998, Mills 1998).

There is little support for ICH-type mechanisms for location of food patches by birds (e.g., Bayer 1982, Mock et al. 1988). Most information exchange at colonies and roosts can be instead attributed to the use of local enhancement (Andersson et al. 1981, Evans 1983, Flemming 1990, Poysa 1992, Smith 1995, Marzluff et al. 1996, Buckley 1996, 1997). In addition, there is growing evidence that marine birds return to the same foraging sites (Benvenuti et al. 1998, Irons 1998, Hedd et al. 2001) and consistently use specific areas, ranging from large water masses to small tidal rips (Cairns and Schneider 1990, Hunt and Harrison 1990, Schneider 1991). Birds also use a combination of strategies. An example of a mixed strategy may be using memory to return to foraging habitats where prey was previously captured then using local enhancement to find specific food patches. The extent to which these strategies are integrated will be influenced by the spatial and temporal resolution at which birds are currently searching, the number of competitors, and the behavior and density of their prey (Russell et al. 1992).

The Common Murre Uria aalge (Pontoppidan 1763) is a long-lived, pursuit-diving marine bird that lays a single-egg clutch in large, dense colonies. The chick is reared at the colony for three weeks, after which it departs the colony with the male parent at $25 \%$ of adult body mass (Gaston and Nettleship 1981). During chick rearing, parents alternate foraging trips, where they travel to a food patch and return to the colony with a single fish for the chick. Murres commonly land on the water in close proximity to the colony prior to departure on a foraging trip ("splashdown area," Burger 1997) and regularly return to the colony in large flocks (Gaston and Nettleship 1981, Burger 1997). To mate successfully, these "central-place foragers" must be proficient at locating food, the difficulty of which is probably linked to general life history traits of seabirds (e.g., single-egg clutch, delayed age of breeding). Seabirds generally favor their own survival over that of their offspring in a given year to maximize the potential for future reproduction (Stearns 1992), but murres can cope with moderate increases in provisioning effort (Burger and Piatt 1990, Monaghan et al. 1994, Uttley et al. 1994). Large flocks of murres returning to colonies provide a potential for murres in the splashdown area to use an ICH-type mechanism to exchange information on the location of foraging habitats beyond visual range of the colony (Gaston and Nettleship 1981, Burger 1997) to mitigate provisioning efforts.

During the breeding season in Newfoundland, murres feed their chicks and themselves primarily female capelin Mallotus villosus (Müller 1776, Davoren 2001). Capelin is a small, schooling, pelagic fish that spawns in large aggregations on or near coastal beaches during summer (Templeman 1948). Capelin schools can be patchily distributed and ephemeral but can also be predictably located within larger areas in different seasons (Schneider 1989, Piatt 1990, Rose and Leggett 1990, Methven and Piatt 1991).

The objective of this study was to examine search strategies used by Common Murres to locate capelin at sea on multiple spatial and temporal scales (Cairns and Schneider 1990). To do this, we quantified individual- and population-level arrival and departure behavior of murres from the colony on the scale of hours via colony- and vessel-based observations during the three-week chick-rearing period (July-August), when birds are limited to forage within $100 \mathrm{~km}$ of the colony (Cairns et al. 1987). We also directly measured the distribution and spatial and temporal persistence of capelin aggregations within the foraging range of murres during chick rearing. We used these observations to infer the relative importance of information exchange and past experience, or memory, in locating foraging habitats from the colony (coarse scale) and in locating food patches within foraging habitats (fine scale). We do not evaluate the use of memory directly but rather use the temporal and spatial persistence of capelin aggregations to indicate whether seabirds could use memory to locate prey. We predict that if capelin aggregations are not persistent in space and time, murres will use a higher degree of information exchange to locate prey. Alternately, if capelin aggregations are persistent, we predict that murres will use a higher degree of memory-based searching. We also compare the search tactics employed by murres with the distribution and behavior of capelin at and around two colonies. These colonies differ in population size, distance from the coast, and bird community diversity. It is important to examine search strategies from multiple areas to understand how predator-prey interactions (e.g., functional responses) differ with divergent foraging and competitor conditions. Establishing the behavioral mechanisms responsible for these interactions is key to understanding linkages among trophic levels and ultimately ecosystem processes. 


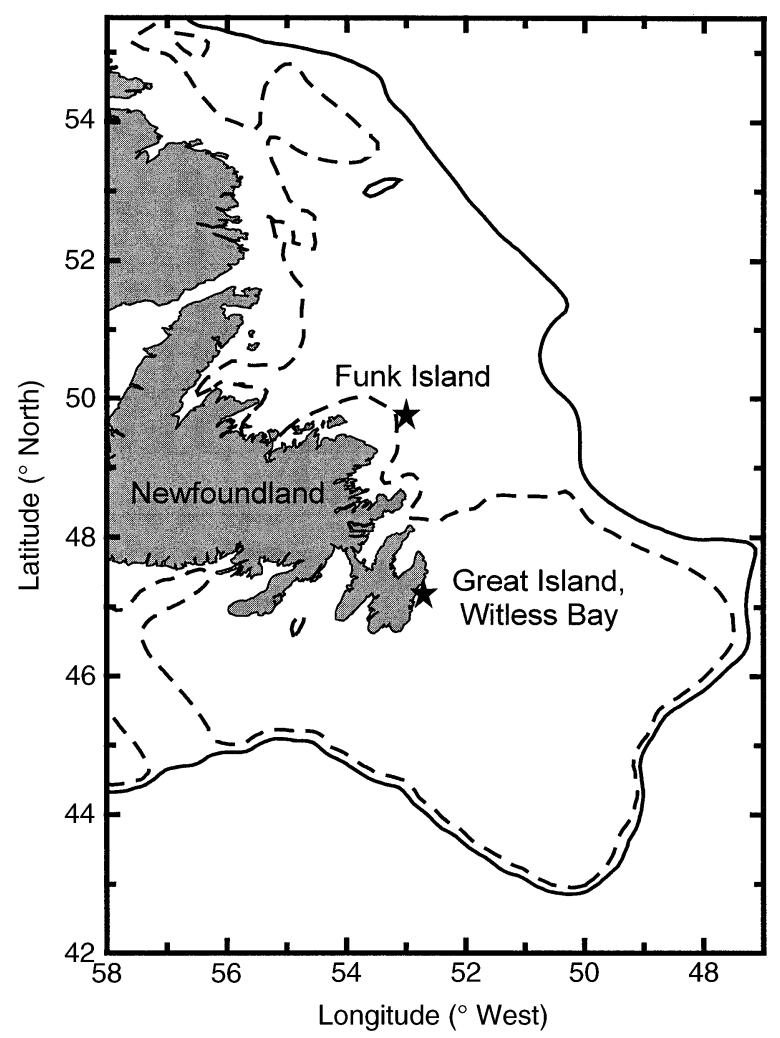

FIG. 1. Map of the Northwest Atlantic showing the Witless Bay (Great Island) and Funk Island Seabird Ecological Reserves off the east coast of Newfoundland and depth contours at $200 \mathrm{~m}$ (dashed line) and $500 \mathrm{~m}$ (solid line).

\section{Methods}

\section{Study area}

This study was conducted during 1998-2000 on and around Great Island $\left(47^{\circ} 11^{\prime} \mathrm{N}, 52^{\circ} 49^{\prime} \mathrm{W}\right)$, Witless Bay, and Funk Island $\left(49^{\circ} 45^{\prime} \mathrm{N}, 53^{\circ} 11^{\prime} \mathrm{W}\right)$ on the east coast of Newfoundland (Fig. 1). Funk Island is $60 \mathrm{~km}$ from the coast, whereas Great Island is $2 \mathrm{~km}$ from the coast (Fig. 1). The population of Common Murres on Funk Island is 340000-400000 breeding pairs (Birkhead and Nettleship 1980), whereas the population in Witless Bay is 100000 pairs (Canadian Wildlife Service, unpublished data). The population of murres in Witless Bay occurs on three islands: Great Island (3000 pairs), Gull Island (1000 pairs) and Green Island (96000 pairs). The Funk Island and Witless Bay areas are 280 $\mathrm{km}$ apart and there are no other large colonies within murre foraging ranges $(\sim 100 \mathrm{~km}$; Cairns et al. 1987, 1990) at either colony.

During this study, murres at both colonies delivered primarily capelin to their chicks $(85-100 \%$ of total food), with smaller percentages of American sand lance Ammodytes americanus (De Kay 1842; 0-15\%, Davoren and Montevecchi 2003). This is consistent with long-term trends at both colonies (Burger and Piatt 1990; Davoren and Montevecchi, in press). A diversity of seabird species breed in Witless Bay and on Funk Island, the proportions of which vary between colonies (Montevecchi and Tuck 1987, Davoren and Montevecchi 2003). This is important because like murres, Atlantic Puffins, Fratercula arctica (Linnaeus 1758), return to colonies in large flocks. At Great Island, 2\% of the birds returning were murres, whereas at Funk Island, 99\% were murres (Cairns et al. 1989). Therefore, most of the information on returning flock direction was from puffins at Great Island, whereas the converse held at Funk Island.

\section{Survey methods}

Vessel-based surveys were conducted around Great and Funk Islands with the objective to determine the location of high abundance areas of capelin and murres within foraging ranges from each colony during July when murres were rearing chicks (Fig. 1). One survey grid was conducted to the southwest of Funk Island $(800 \mathrm{~km})$ in 2000 aboard a 23-m Canadian Coast Guard Vessel (Shamook). This grid was established based on preliminary observations of returning flight directions of murres toward Funk Island in 1997, observations of high-density capelin-murre aggregations en route to Funk Island from 1977 to 1997 (W. A. Montevecchi, unpublished data) and the location of traditional fishing areas for capelin (L. Easton, personal communication). A more limited survey $(35 \mathrm{~km})$ was conducted around Great Island in 1998, owing to the use of a smaller 8$\mathrm{m}$ fishing vessel (Molly Bawn). A survey route was established rather than a grid to maximize the linear distance covered from the colony. This route was based on commuter routes of murres toward and away from Witless Bay (Schneider et al. 1990), observations of high-density capelin-murre aggregations en route to Great Island in 1997-1998 (e.g., Mobile Bay; G. K. Davoren, unpublished data) and the location of traditional fishing areas of capelin (T. Reddick, personal communication). Breeding success of murres (percentage of chicks departing breeding sites out of the number hatched) was consistent at study plots on each colony among years (Great Island, 80-88\%; Funk Island, 66-68\%; Davoren 2001) and, thus, we advocate that prey conditions were similar around each colony throughout all years of this study.

A Simrad EQ100 echo-sounding system (Simrad AS, Horten, Norway) was used aboard the Shamook and a Furuno FCV-291 system (Furono USA, Camas, Washington, USA) aboard the Molly Bawn. Both systems operated through a hull-mounted, single-beam transducer at a frequency of $38 \mathrm{kHz}$. This frequency is appropriate for observations of fish targets and the distinct shape of capelin schools allows them to be separated from other fish species (e.g., American sand lance and Atlantic herring Clupea harengus harengus (Linnaeus 1758) within the study area (O'Driscoll et al. 2002). The quality of the two echo sounders varied substantially but both were similarly capable of deter- 
mining the presence/absence of fish at the range of depths encountered during surveys $(<250 \mathrm{~m})$ and of displaying visual representations of school structure on printed echograms. The transducers operated at 1 ping per second, a range of $250 \mathrm{~m}$, and a bandwidth of $0.4-$ $0.6 \mathrm{~ms}$. Transducers were at a depth of $3 \mathrm{~m}$ and beam pattern would not form within a range of $5 \mathrm{~m}$, therefore, acoustic signals were not reliable until $8 \mathrm{~m}$. The sample depth of the acoustic systems $(8-250 \mathrm{~m})$ and vessel speeds $(14-16 \mathrm{~km} / \mathrm{h})$ were held constant throughout all surveys. Echograms were continuously printed during both surveys and Greenwich Mean Time (GMT) was marked on echograms every $10 \mathrm{~min}$. A navigational software package (Bioplot version 2.0; BioSonics, Seattle, Washington, USA) continuously recorded ship position (latitude and longitude) and GMT every minute (cruise track).

The survey grid around Funk Island was periodically interrupted to identify the species composition of acoustic signals using a modified shrimp trawl deployed from the Shamook. The total mass of the catch and the mass of capelin within the catch were recorded immediately after each tow. Trawling was not possible from the Molly Bawn and, thus, the species composition of acoustic signals around Great Island was not determined. During surveys, however, fish in the bills of birds were identified as were fish schools near the ocean surface observed from the vessel.

During acoustic transects, seabirds were counted simultaneously using standard strip transect methods (Method Ib, Tasker et al. 1984). One observer made continuous counts of seabirds from the bridge out to 300 $\mathrm{m}$ in a $90^{\circ}$ arc from the tip of the bow to the port side of the vessel. Counts were entered directly into a laptop computer along with behavioral descriptions (on water, feeding, flying and direction, flying with fish). The laptop was interfaced with the navigational system of the vessel or a hand-held Global Positioning System (Garmin 3, Garmin, Olathe, Kansas, USA) and counting software (D. Senciall, Birds \& Beasty Counter, version 1.0, Fisheries and Oceans Canada, St. John's, Newfoundland, Canada) was used to append a position (latitude and longitude) and GMT to each bird entry. The date and GMT were used to merge bird data with acoustic estimates and the cruise track into $1 \mathrm{~min}(250 \mathrm{~m})$ bins.

\section{Analysis of survey data}

Following Piatt (1990), the relative abundance of fish was quantified by estimating the percentage cover of the prey image in each $1 \mathrm{~min}(250 \mathrm{~m})$ by $10 \mathrm{~m}$ vertical bin on the echogram. An index of percentage cover of prey in each bin was estimated from 0 (no prey) to 9 (near saturation). These values were squared before analysis (0-81) to account for the nonlinear change in sounder intensity relative to fish school density (Piatt 1990). This squared relative measure is hereafter referred to as the "acoustic abundance score." This technique allowed us to quantify the presence/absence of fish and relative abundance of fish and to evaluate the shape of fish schools. Owing to the variability in the quality of the two echo sounders used, comparison of acoustic abundance scores should be limited to intrasounder estimates. At-sea observations, species composition of trawl sets, and shapes of acoustic schools on echograms were combined to classify the acoustic signals representing capelin schools.

Haney et al. (1992) estimated that birds on the water could visually cue to the foraging activities of other birds within a distance of $4.5 \mathrm{~km}$. We assumed that a murre would be able to locate food patches by observing the foraging activities of conspecifics and other marine animals within $4.5 \mathrm{~km}$ based on this estimate and based on the high densities of birds found around both colonies. Acoustic abundance scores due to capelin in the $250 \mathrm{~m}$ horizontal by $10 \mathrm{~m}$ vertical blocks were summed over the water column and then the mean capelin acoustic abundance scores per $2.25-\mathrm{km}$ block were calculated by averaging these $250 \mathrm{~m}$ depth integrated scores. These $2.25-\mathrm{km}$ blocks are referred to as "foraging habitats," within which capelin schools could be found. The mean acoustic abundance scores for all nonzero $2.25-\mathrm{km}$ foraging habitats were averaged over the entire survey. Only nonzero values were used in these calculations to determine the mean abundance of capelin and murres in foraging habitats without incorporating features of distribution patterns (i.e., number of zero foraging habitats). Foraging habitats with higher than mean capelin acoustic abundance scores during the initial surveys were defined as "hot spots" (Cairns and Schneider 1990).

Hot spots found in the initial surveys were revisited on two or three occasions within a two-week period of the initial survey around each colony. The interval between visits varied from 3 to 14 days. Upon each visit, a $2.25-\mathrm{km}$ acoustic transect was conducted simultaneously with bird counts along the initial survey route. A fishing set was conducted within hot spots (at Funk Island only) to determine whether species composition of fish schools changed over the two-week period.

The persistent presence of acoustic capelin schools and murres, or "persistence," was estimated within hot spots by dividing the number of times each $2.25-\mathrm{km}$ transect contained capelin and murres by the number of times the hot spot was visited (initial survey and other visits). For example, if capelin was present on two of four visits and murres were present on only one visit within a specific hot spot, this hot spot would receive a persistence score of $50 \%$ for capelin and $25 \%$ for murres. The mean acoustic abundance score due to capelin \pm 1 SE was also calculated in each $2.25-\mathrm{km}$ hot spot over all visits. The SE was used as a measure of "variability" in relative abundance estimates.

\section{Return, departure, and splashdown area behavior of murres}

Population-level return behavior of murres was observed in 1998, 1999, and 2000 at Great and Funk 
Islands. Scans were always conducted from the same site, which was the highest point on each island, allowing a complete $360^{\circ}$ aspect, except at Great Island where one $45^{\circ}$ sector $\left(315-360^{\circ}\right)$ was partially obscured by another high point of land. Scan sites were situated on the northeast section of both colonies and were elevated above breeding sites of murres. Each $45^{\circ}$ sector was scanned for $1 \mathrm{~min}$ using the same compassequipped binoculars $(7 \times 50)$ with the horizon in the midline of view. The number of birds returning in each sector was noted on a tape recorder. It was at times difficult to distinguish between flying murres and puffins at a distance, so all birds were recorded and whenever possible these species were differentiated. Mixed species feeding assemblages of birds and whales observed in each $45^{\circ}$ sector were also recorded. Three $360^{\circ}$ rotations were conducted and defined as a $360^{\circ}$ scan, lasting a total of $24 \mathrm{~min}$. Before and after each $360^{\circ}$ scan, weather variables (visibility, precipitation, wind speed $[\mathrm{km} / \mathrm{h}$, using a hand-held anemometer], and direction) were recorded.

Individual-level departure behavior of murres was always observed from the $360^{\circ}$-scan site at both colonies, immediately after each $360^{\circ}$ scan in 1999 and 2000 . The same site was always used at each colony for return and departure observations to minimize biases in the subjective determination of flight directions and to maximize the accuracy of flight directions. At Great Island, 10 individuals were chosen haphazardly and each was followed as it departed a breeding ledge. Individuals were observed leaving departure ledges on Funk Island rather than breeding ledges because murres nest densely on flat ground in the center of the island. We recorded whether each individual flew directly out to sea (direct departure) or landed in the vicinity of the colony (splashdown area, splashdown departure; see Burger 1997). The final bearing of birds directly departing the colony was recorded. Birds in flight could be followed for up to 2 min, or $\sim 2 \mathrm{~km}$ based on a flight speed of $60 \mathrm{~km} / \mathrm{h}$ (Pennycuick 1987). Zigzag flight was observed within the first minute but flight direction generally stabilized before the bird was lost from view. The final bearing of birds departing into the splashdown area also was recorded. Birds from the same breeding or departure ledge did not land in the same region of the splashdown area (G. K. Davoren, unpublished data). Individuals that landed in the splashdown area were lost due to high densities of conspecifics and, thus, the final bearings of splashdown departures were not used further. We chose 10 individuals leaving different regions of the splashdown area and recorded the final bearing of departure. These 20 departures were defined as a departure scan, lasting $\sim 40 \mathrm{~min}$. The final bearings of direct and splashdown departures were recorded separately. The $360^{\circ}$ and departure scans together were defined as a sample period, lasting $\sim 1 \mathrm{~h}$.

The departure behavior of known individual murres was also observed from a blind throughout daylight on
Great Island in 1998 and 1999 to determine if individuals departed in the same direction upon successive foraging trips. Approximately 50 murres were marked with yellow dye (picric acid) for individual recognition in a subcolony situated $\sim 10 \mathrm{~m}$ from the blind (see Davoren and Montevecchi 2003). The final bearing of directly departing individuals was recorded.

The behavior of individuals was observed in the splashdown area at both colonies in 1998 to determine the time birds spend idle in the area, or the time available to cue to flight trajectories of returning birds, prior to departure on a foraging trip. Individuals were followed upon departure from colony ledges and the behavior of focal individuals was recorded for up to 5 min, or less if the individual left the area. Instantaneous scans of birds in this area were also conducted to compare whether the percentage of murres loafing in splashdown areas differed between colonies, as it was very difficult to track focal birds for $5 \mathrm{~min}$ due to confusion with conspecifics. Instantaneous visual scans were conducted using a $15-40 \times$ spotting scope from the $360^{\circ}$ scan site. The number of murres head dipping, loafing, and preening/bathing in the splashdown area were counted during three consecutive 5-min intervals.

\section{Analysis of behavioral data}

The weather data were used to eliminate sample periods when visibility was compromised. The total numbers of birds returning to the colony during each $360^{\circ}$ scan and departing the colony in each departure scan were calculated for each $45^{\circ}$ sector. Birds directly departing nesting ledges and birds departing the splashdown area were analyzed separately. The mean and modal angles of return and departure were calculated following Batschelet (1981). A Rayleigh Test was conducted on each $360^{\circ}$ scan and each departure scan to determine if return and departure directions were random (Batschelet 1981). Circular correlations were conducted on the mean angles of return and departure flights in consecutive sample periods to determine their degree of association (Zar 1996). The mean angles of departure and return flights during the same sample period were compared using circular correlations. Circular correlations also were run on the angles of consecutive direct departures by each marked murre observed from the blind on Great Island to determine the temporal persistence of individual departure directions. Results from circular correlations are reported as the upper and lower circular correlation coefficients and are deemed not significant (NS, $\alpha=0.05$ ) if these coefficients span zero (Zar 1996). Statistical significance for all other tests was set at $\alpha=0.05$ and all means are reported with \pm 1 SE.

Wind direction for each sample period was assigned to the appropriate $45^{\circ}$ sector. All sample periods were divided into two wind speed categories: $<$ and $\geq 25$ $\mathrm{km} / \mathrm{h}$, because observations of individual flight behavior at wind speeds $<25 \mathrm{~km} / \mathrm{h}$ revealed unwavering flight, 
whereas wind gusts were customary at $\geq 25 \mathrm{~km} / \mathrm{h}$ and individual flight behavior was unsteady, with individuals often thrown off a steady course by gusts. Circular correlations were run on wind and return mean angles and wind and mean departure angles within sample periods for each wind speed category to determine whether wind direction influenced return or departure directions and whether low and high wind speeds influenced flight directions differentially.

The time spent loafing during the first 5 min of landing in the splashdown area by each individual was compared between colonies ( $t$ test). We determined whether the proportion of birds that left the splashdown area within $5 \mathrm{~min}$ and the number that stayed at least $5 \mathrm{~min}$ differed between colonies ( $\chi^{2}$ test). For instantaneous scans, the number of murres resting in the splashdown area during each successive 5-min scan was summed to obtain 15-min totals. The total number of murres loafing did not differ throughout the day (Davoren 2001), so scans from all times of day were pooled. We determined if the proportion of loafing birds versus active birds (preening, bathing, and head dipping) in the splashdown area differed between colonies ( $\chi^{2}$ test).

\section{RESULTS}

\section{Abundance and distributions of capelin and murres}

During the initial survey around Funk Island in 2000, a total of $3532.25-\mathrm{km}$ blocks were surveyed, $58 \%$ of which contained murres, $41 \%$ contained capelin, and $30 \%$ contained capelin and murres. Seventeen fishing sets were conducted, during which $96 \%$ of catches, by mass, were capelin.

The mean acoustic abundance score due to capelin for all nonzero $2.25-\mathrm{km}$ foraging habitats during the initial survey around Funk Island was $0.8 \pm 0.1$ (mean $\pm 1 \mathrm{SE}$ ) and the mean murre abundance for all nonzero blocks was $2.9 \pm 0.5$. Nineteen foraging habitats had capelin abundances above average $(5 \%)$ during the initial survey and these were defined as "hot spots." Due to time restrictions, 14 of these hot spots in three general areas were revisited over a two-week period (Fig. 2). Capelin were $100 \%$ persistent, or always present, in two of these areas, which consisted of three hot spots (Area 1 included hot spots 1 and 2; Area 3 included hot spot 14; Fig. 2). Capelin abundance in these three hot spots remained above the mean among visits (Table 1). Murres were always present in these hot spots and were generally observed either diving or sitting on the water with fish in their bills. Abundances of murres in these hot spots, however, varied widely among visits (Table 1). Area 2 consisted of 11 hot spots (3-13), four of which had $100 \%$ persistent capelin but seven of which had less consistent presence of capelin (Fig. 2; Table 1). Capelin abundance in these hot spots varied among visits and was not consistently above the mean (Fig. 2, Table 1). Similarly, both the presence and abundance of murres within hot spots in Area 2 were var- iable (Table 1). The percentage by number of bird species other than Common Murres observed within these hot spots was negligible $(<1 \%)$.

During trawling, we observed that capelin schools encountered in Area 2 were always ephemeral. Therefore, although capelin was $100 \%$ persistent within four hot spots in Area 2 over a two-week period, capelin schools within these hot spots were highly mobile. In contrast, capelin schools in Areas 1 and 3 were located in the exact same position on different days and, thus, were highly stationary.

During the limited initial survey conducted around Great Island in 1998, $162.25-\mathrm{km}$ blocks were surveyed: $69 \%$ contained capelin, $69 \%$ contained murres, and $56 \%$ contained capelin and murres. All prey items observed in the bills of birds $(n=49)$ and schools observed near the ocean's surface $(n=10)$ around Great Island were capelin. The mean acoustic abundance score due to capelin \pm 1 SE for all nonzero 2.25 $\mathrm{km}$ foraging habitats was $1.1 \pm 0.3$ and the mean murre abundance was $18.0 \pm 9.7$ during the initial survey. Five (45\%) 2.25-km foraging habitats contained mean capelin acoustic abundance scores above the mean; these were defined as "hot spots" and were revisited over a one week period (Fig. 3). Capelin was always present, or $100 \%$ persistent, in four hot spots $(1,3,4$, and 5) two of which had abundances that were consistently above the mean for both capelin and murres (3 and 4; Table 1). The other hot spot (2) had lower abundances of murres and capelin that were variable (Table 1). The percentage by number of bird species other than Common Murres observed within these hot spots was low $(<16 \%)$.

\section{Returns}

Two hundred $360^{\circ}$ scans were conducted (Funk Island, $n=88$; Great Island, $n=112$ ), where the total number of individuals observed during a scan ranged from 15 to 1854 at Great Island and from 228 to 6060 at Funk Island. Birds generally returned to both colonies from all eight sectors during each $360^{\circ}$ scan; however, return directions were always nonrandom (Table 2). The modal direction of return toward Great Island $\left(180^{\circ}-225^{\circ}\right)$ and toward Funk Island $\left(225^{\circ}-270^{\circ}\right)$ was consistent among years (Table 2) and, thus, years were pooled. Return directions were positively correlated with those in subsequent sample periods (Table 3; Fig. 4a), indicating that return directions remained consistent within and among days.

Mixed-species feeding assemblages, marking ephemeral food patches, were observed within visual range only from Great Island in all years. This indicated that murres could use local enhancement, or visually cue to the foraging activities of conspecifics and other marine animals, to locate food patches from Great Island but not from Funk Island. These feeding assemblages included Common Murres, Atlantic Puffins, Black-legged Kittiwakes, Rissa tridactyla (Linnaeus 

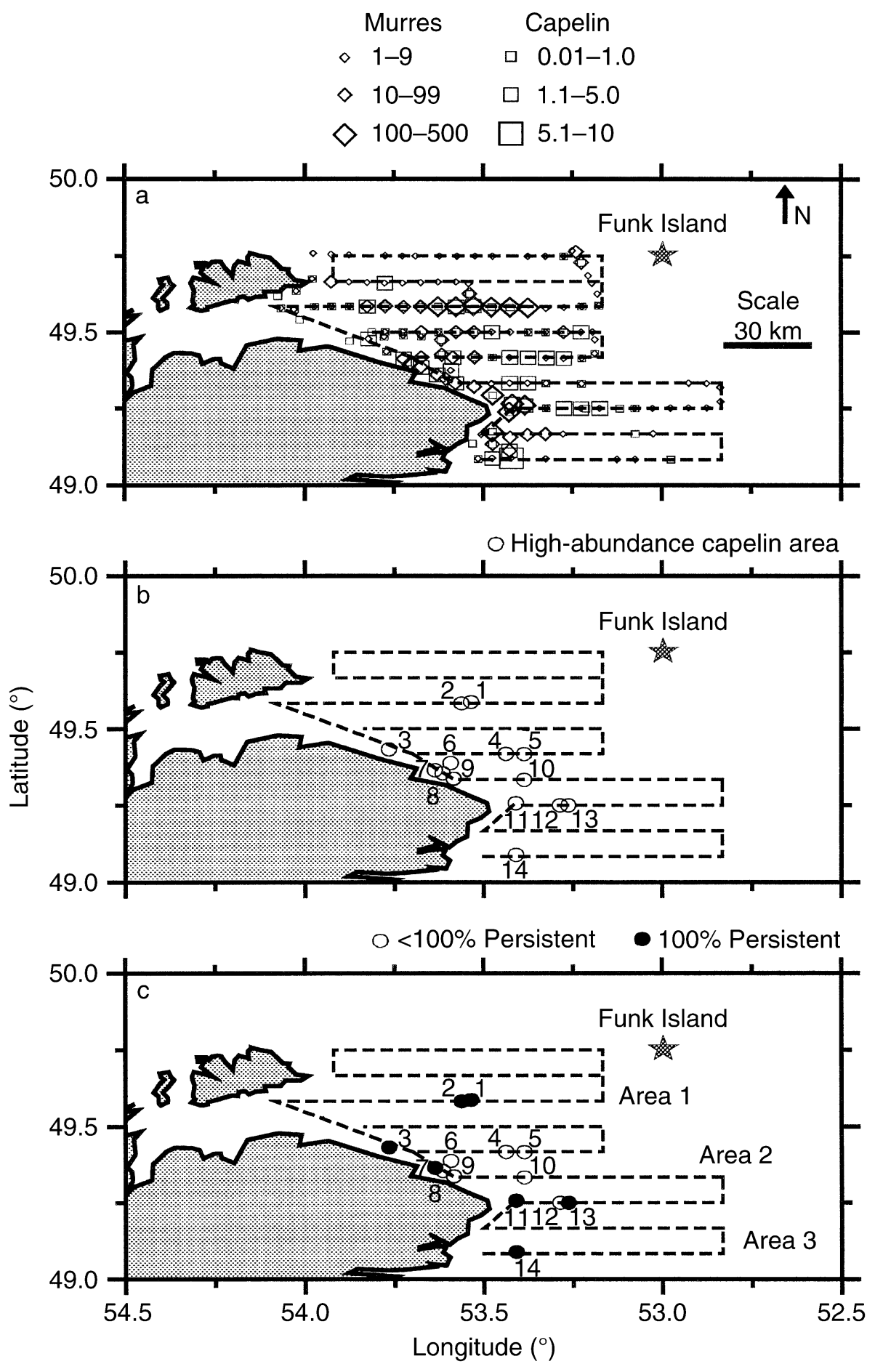

FIg. 2. (a) The distribution and abundance of Common Murres (Uria aalge) and capelin (Mallotus villosus) around Funk Island in 2.25-km bins, (b) the location of capelin "hot spots" (bins with capelin abundance higher than the mean), and (c) the persistence of capelin presence at each "hot spot" on all visits. Dashed lines indicate transect routes. 
TABLE 1. The persistence and mean relative abundance of capelin (Mallotus villosus) and Common Murres (Uria aalge).

\begin{tabular}{|c|c|c|c|c|c|c|}
\hline \multirow[b]{2}{*}{ Location } & \multicolumn{3}{|c|}{ Capelin } & \multicolumn{3}{|c|}{ Murre } \\
\hline & No. visits & Persistence (\%) & $\begin{array}{c}\text { Abundance } \\
\text { (capelin/hot spot) }\end{array}$ & No. visits & Persistence (\%) & $\begin{array}{c}\text { Abundance } \\
\text { (murres/hot spot) }\end{array}$ \\
\hline \multicolumn{7}{|c|}{$\begin{array}{l}\text { Funk Island } \\
\text { Area } 1\end{array}$} \\
\hline 1 & 3 & 100 & $1.21 \pm 0.31$ & 3 & 100 & $17.59 \pm 13.00$ \\
\hline 2 & 4 & 100 & $1.05 \pm 0.22$ & 4 & 100 & $3.03 \pm 2.39$ \\
\hline \multicolumn{7}{|l|}{ Area 2} \\
\hline 3 & 3 & 100 & $0.80 \pm 0.63$ & 3 & 100 & $1.00 \pm 0.88$ \\
\hline 4 & 4 & 75 & $1.02 \pm 0.79$ & 4 & 75 & $2.07 \pm 1.34$ \\
\hline 5 & 4 & 50 & $0.51 \pm 0.50$ & 3 & 67 & $0.29 \pm 0.26$ \\
\hline 6 & 4 & 25 & $0.26 \pm 0.25$ & & & \\
\hline 7 & 3 & 100 & $1.02 \pm 0.90$ & 3 & 67 & $0.98 \pm 0.91$ \\
\hline 8 & 3 & 67 & $0.85 \pm 0.78$ & 3 & 67 & $2.78 \pm 2.47$ \\
\hline 9 & 4 & 75 & $0.56 \pm 0.47$ & 4 & 50 & $2.96 \pm 2.91$ \\
\hline 10 & 3 & 67 & $0.37 \pm 0.32$ & 4 & 50 & $2.71 \pm 1.74$ \\
\hline 11 & 4 & 100 & $0.25 \pm 0.24$ & 3 & 67 & $2.85 \pm 2.52$ \\
\hline 12 & 3 & 67 & $0.65 \pm 0.59$ & 3 & 67 & $1.01 \pm 0.87$ \\
\hline 13 & 3 & 100 & $0.86 \pm 0.76$ & & & \\
\hline \multicolumn{7}{|l|}{ Area 3} \\
\hline 14 & 3 & 100 & $5.90 \pm 2.58$ & 4 & 100 & $1.00 \pm 0.78$ \\
\hline \multicolumn{7}{|c|}{ Great Island } \\
\hline 1 & 3 & 100 & $0.65 \pm 0.58$ & 3 & 100 & $7.19 \pm 4.77$ \\
\hline 2 & 3 & 67 & $0.89 \pm 0.78$ & 3 & 100 & $6.89 \pm 7.58$ \\
\hline 3 & 3 & 100 & $2.00 \pm 0.08$ & 3 & 100 & $34.15 \pm 32.48$ \\
\hline 4 & 3 & 100 & $2.50 \pm 1.00$ & 3 & 100 & $51.00 \pm 44.00$ \\
\hline 5 & 3 & 100 & $1.02 \pm 0.82$ & 3 & 100 & $10.59 \pm 13.14$ \\
\hline
\end{tabular}

Notes: Values are shown as mean \pm 1 SD for each numbered $2.25-\mathrm{km}$ hot spot (area with higher than mean capelin abundance scores) that was visited for observation around Funk Island in 2000 and Great Island in 1998. Persistence is calculated as number of observation visits (initial survey and other visits) with murres or capelin present divided by the total number of visits.

1758), and humpback whales, Megaptera novaeangliae (Borowski 1781). Feeding assemblages were consistent with type I feeding flocks described by Hoffman et al. (1981), persisted from minutes to hours, and were located in different areas within and among days. Prey types at these assemblages were not determined and murres were never observed with fish in their bills at these assemblages, even though close observations were possible during boat surveys.

\section{Departures}

One hundred and twelve departure scans were conducted (Great Island, $n=76$; Funk Island, $n=36$ ), during which the number of individuals observed during a scan ranged from 13 to 23 individuals. Overall, 1493 individuals were observed departing the colonies (Great Island, $n=1254$; Funk Island, $n=239$ ). A significantly higher percentage of birds directly departed ledges at Great Island (30\%) compared to Funk Island in all years $\left(7 \% ; \chi^{2}=53.90, \mathrm{df}=1, n=1493\right.$, $P<0.001)$. Therefore, we consider a single departure strategy at Funk Island (splashdown departure) and two at Great Island (splashdown and direct departure).

Murres generally departed both the nesting ledge and the splashdown area in all eight sectors during each departure scan. The modal direction of departure from Great Island $\left(180^{\circ}-225^{\circ}\right)$ and Funk Island $\left(225^{\circ}-270^{\circ}\right)$ was consistent among years of this study (Table 2) and, thus, years were pooled. At Funk Island, 81\% ( $n=$ 239) of the birds departing the splashdown area left the vicinity of the colony alone, while others left in flocks of 2-13 individuals. At Great Island, 89\% $(n=$ 487) of the birds departing the splashdown area left the vicinity of the colony alone, while others left in flocks of $2-15$ individuals. Similarly, 94\% $(n=290)$ of birds departing the nesting ledge at Great Island left the vicinity of the colony alone. At both colonies, 33$43 \%$ of the sampling periods had nonrandom departure directions from the splashdown area (Table 2). The frequency of nonrandom departure directions from the splashdown area all years combined did not differ between Great and Funk Islands $\left(\chi^{2}=0.68\right.$, df $=1, n=$ $112, P=0.04$; Table 2). At Great Island, there were significantly fewer sample periods with nonrandom direct departure directions from the colony compared to departure directions from the splashdown area all years combined $\left(\chi^{2}=11.44\right.$, df $=1, n=133, P<0.001$; Table 2).

At both colonies in all years, departure directions from the splashdown area were negatively correlated with departure directions in subsequent sample periods within days (Table 3; Fig. 4b), indicating that departure directions were not consistently in the same direction within days. In contrast, directions of direct departure 

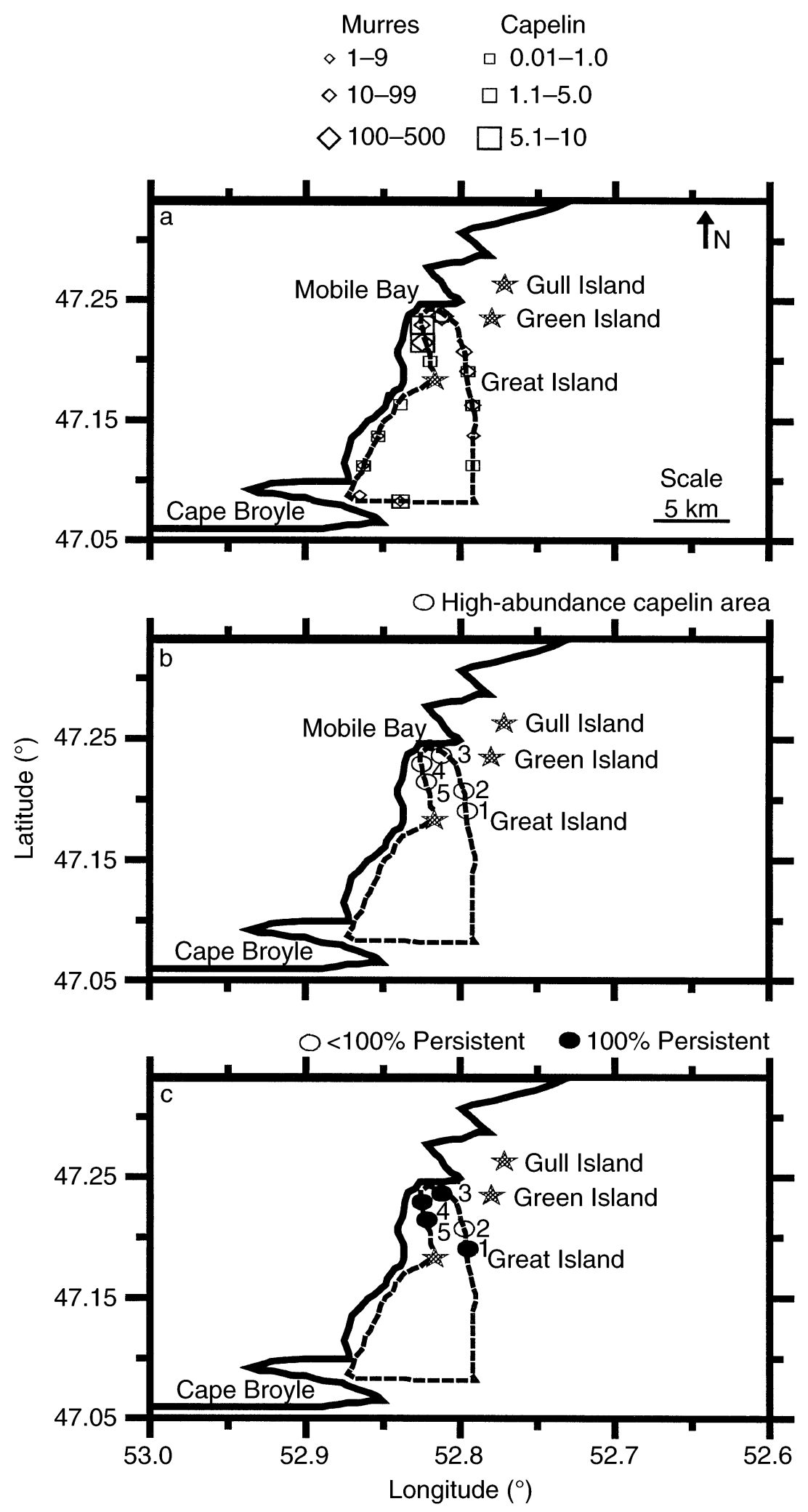

FIg. 3. (a) The distribution and abundance of Common Murres (Uria aalge) and capelin (Mallotus villosus) around Great Island, Witless Bay in 2.25-km bins, (b) the location of capelin "hot spots" (bins wth capelin abundance higher than the mean), and (c) the persistence of capelin presence at each "hot spot" on all visits. Dashed lines indicate transect routes. 
TABLE 2. The number of scans during which individual Common Murres (Uria aalge) returned and departed the colony in a significantly nonrandom or random manner, using Rayleigh Tests, and the modal direction of return and departure of murres in each year at Funk Island and Great Island during 1998-2000.

\begin{tabular}{|c|c|c|c|c|c|c|c|c|}
\hline \multirow[b]{2}{*}{ Category } & \multicolumn{4}{|c|}{ Funk Island } & \multicolumn{4}{|c|}{ Great Island } \\
\hline & 1998 & 1999 & 2000 & All years & 1998 & 1999 & 2000 & All years \\
\hline \multicolumn{9}{|l|}{ Return flight } \\
\hline $\begin{array}{l}\text { Nonrandom } \\
\text { Random }\end{array}$ & $\begin{array}{r}37 \\
0\end{array}$ & $\begin{array}{r}28 \\
0\end{array}$ & $\begin{array}{r}23 \\
0\end{array}$ & $\begin{array}{r}88 \\
0\end{array}$ & $\begin{array}{r}16 \\
0\end{array}$ & $\begin{array}{r}55 \\
0\end{array}$ & $\begin{array}{r}41 \\
0\end{array}$ & $\begin{array}{r}112 \\
0\end{array}$ \\
\hline Total & 37 & 28 & 23 & 88 & 16 & 55 & 41 & 112 \\
\hline $\begin{array}{l}\text { Percentage nonran- } \\
\text { dom }\end{array}$ & 100 & 100 & 100 & 100 & 100 & 100 & 100 & 100 \\
\hline $\begin{array}{l}\text { Modal return direc- } \\
\text { tion }\end{array}$ & $180^{\circ}-225^{\circ}$ & $225^{\circ}-270^{\circ}$ & $225^{\circ}-270^{\circ}$ & $225^{\circ}-270^{\circ}$ & $180^{\circ}-225^{\circ}$ & $180^{\circ}-225^{\circ}$ & $180^{\circ}-225^{\circ}$ & $180^{\circ}-225^{\circ}$ \\
\hline \multicolumn{9}{|c|}{ Departure from splashdown area } \\
\hline Nonrandom & $\ldots$ & 5 & 8 & 13 & $\ldots$ & 16 & 15 & 31 \\
\hline Random & $\ldots$ & 10 & 13 & 23 & $\ldots$ & 25 & 20 & 45 \\
\hline $\begin{array}{l}\text { Total splashdown } \\
\text { area departures }\end{array}$ & $\cdots$ & 15 & 21 & 36 & $\cdots$ & 41 & 35 & 76 \\
\hline $\begin{array}{l}\text { Percentage nonran- } \\
\text { dom }\end{array}$ & $\cdots$ & 33 & 38 & 36 & $\cdots$ & 39 & 43 & 41 \\
\hline $\begin{array}{l}\text { Modal departure di- } \\
\text { rection }\end{array}$ & $\cdots$ & $225^{\circ}-270^{\circ}$ & $225^{\circ}-270^{\circ}$ & $225^{\circ}-270^{\circ}$ & $\cdots$ & $180^{\circ}-225^{\circ}$ & $180^{\circ}-225^{\circ}$ & $180^{\circ}-225^{\circ}$ \\
\hline \multicolumn{9}{|l|}{ Direct departure } \\
\hline Nonrandom & $\ldots$ & $\ldots$ & $\ldots$ & $\ldots$ & $\ldots$ & 6 & 9 & 15 \\
\hline Random & $\ldots$ & $\ldots$ & $\ldots$ & $\ldots$ & $\ldots$ & 32 & 20 & 52 \\
\hline $\begin{array}{l}\text { Total direct depar- } \\
\text { tures }\end{array}$ & $\cdots$ & $\cdots$ & $\cdots$ & $\cdots$ & $\cdots$ & 38 & 29 & 67 \\
\hline $\begin{array}{l}\text { Percentage nonran- } \\
\text { dom }\end{array}$ & $\ldots$ & $\cdots$ & $\cdots$ & $\cdots$ & $\cdots$ & 16 & 31 & 22 \\
\hline $\begin{array}{l}\text { Modal departure di- } \\
\text { rection }\end{array}$ & $\cdots$ & $\cdots$ & $\cdots$ & $\cdots$ & $\cdots$ & $135^{\circ}-180^{\circ}$ & $180^{\circ}-225^{\circ}$ & $180^{\circ}-225^{\circ}$ \\
\hline
\end{tabular}

from Great Island were positively correlated with directions in subsequent sample periods within days (Table 3; Fig. 4c). Successive direct departure directions of marked individuals observed from the blind at Great Island were positively correlated within days (Table 3 ). A significantly higher percentage of murres landed at mixed species feeding assemblages from the splashdown area $(10 \pm 3 \%)$ than from nesting ledges $(4 \pm$ $2 \% ; t=2.01$, df $=30, P=0.04)$ when these assemblages were visible from the colony.

\section{Splashdown behavior}

Upon departing from ledges and landing in the splashdown areas adjacent to each colony in 1998, murres began immediately to preen, bathe, and head dip. Significantly more birds left the splashdown area within the first $5 \mathrm{~min}$ at Funk Island $(50 \%, n=20)$ compared to the Great Island $\left(11 \%, n=38 ; \chi^{2}=9.10\right.$, df $=1, n=58, P<0.001)$. Of the murres that departed within the first $5 \mathrm{~min}$, those at Great Island loafed on the water significantly longer after preening and bathing but before departing $(74.5 \pm 5.9 \mathrm{~s})$ than those at Funk Island $(2.8 \pm 0.5 \mathrm{~s} ; t=21.24, \mathrm{df}=12, P<$ 0.0001). Together, these results indicate that murres spent less time loafing in the vicinity of Funk Island relative to Great Island. Instantaneous visual scans corroborated this result: a significantly lower percentage of murres were loafing in the splashdown area at Funk
Island $(36 \pm 3 \%$, number of scans $=38)$ compared to Great Island $\left(47 \pm 2 \%, n=37 ; \chi^{2}=104.15, \mathrm{df}=1\right.$, $n=75, P<0.001)$.

\section{Returns and departures}

Return directions were negatively correlated with departure directions at both colonies during the same sample period (Table 3; Fig. 4d, e). Commuting routes (regular flight paths towards and away from colonies; Schneider et al. 1990) of murres, however, were observed farther away from each colony at sea. Commuting routes of murres around Funk Island were along a northeast-southwest line that was consistent with the locations of persistent hot spots of capelin and murres (Fig. 5a, b). There also appeared to be movement among persistent hot spots (Fig. 5c). Commuting routes of murres around Great Island were along a north-south line (Fig. 6a, b) that was consistent with the routes and foraging areas previously described by Schneider et al. (1990). Flight directions at sea also indicated that the persistent hot spot in Mobile Bay was an important foraging area (Fig. 6c).

\section{Wind}

The modal wind direction at Funk Island was from $135^{\circ}-270^{\circ}$ and at Great Island was from $180^{\circ}-270^{\circ}$ in all years. At Funk Island, returning birds generally flew with the wind (positive correlation) at wind speeds of 
TABLE 3. Circular correlation coefficients (lower and upper) for the mean angle of departure and return of Common Murres (Uria aalge) at Funk and Great Islands (1999 and 2000 data combined).

\begin{tabular}{|c|c|c|c|c|c|c|}
\hline \multirow[b]{2}{*}{ Foraging flights } & \multicolumn{3}{|c|}{ Funk Island } & \multicolumn{3}{|c|}{ Great Island } \\
\hline & Lower & Upper & No. scans & Lower & Upper & No. scans \\
\hline Returns vs. departures from splashdown area & -0.1120 & -0.0937 & 35 & -0.1462 & -0.1403 & 60 \\
\hline Returns vs. direct departures & $\ldots$ & $\ldots$ & $\cdots$ & -0.2223 & -0.2104 & 46 \\
\hline Successive returns & 0.5860 & 0.5978 & 51 & 0.3993 & 0.4046 & 73 \\
\hline Successive departures from splashdown area & -0.0872 & -0.0540 & 20 & -0.3782 & -0.3635 & 42 \\
\hline Successive direct departures & $\ldots$ & $\ldots$ & $\ldots$ & 0.3150 & 0.3340 & 31 \\
\hline Successive direct departures by individual murres & $\ldots$ & $\ldots$ & $\ldots$ & 0.5151 & 0.5959 & 15 \\
\hline
\end{tabular}

Notes: All data were significantly correlated $(\alpha=0.05)$. See Methods for a description of scan methods.

$<25 \mathrm{~km} / \mathrm{h}$ but flew into the wind (negative correlation) at wind speeds $\geq 25 \mathrm{~km} / \mathrm{h}$ (Table 4 ). In contrast, murres departing from the splashdown area flew with the wind upon departure at wind speeds $<25 \mathrm{~km} / \mathrm{h}$ and departure directions at wind speeds $\geq 25 \mathrm{~km} / \mathrm{h}$ were variable (not correlated with wind direction). At Great Island, returning murres and murres departing from the splashdown area generally flew with the wind (Table 4), whereas murres directly departing ledges generally flew into the wind (Table 4). Overall, directions of flight were variable and inconsistently related to wind direction and speed.

\section{DISCUSSION}

Departure flight directions were not consistent with return flight directions of murres during a sample period $(\sim 1 \mathrm{~h})$ at either colony, indicating that murres departing colonies did not use information on distant foraging locations provided by the flight paths of returning flocks carrying fish. Hot spots of capelin, however, were persistent at the level of meters, $2.25 \mathrm{~km}$, and $4.5 \mathrm{~km}$ (adjacent 2.25-km blocks) over two weeks within the foraging ranges of murres from both colonies during chick rearing. These circumstances suggest that murres could use memory to locate both hot spots of capelin (on a coarse scale of $1-100 \mathrm{~km}$ ) and capelin schools within hot spots (on a fine scale of 1-1000 m) while rearing chicks. Commuting routes (regular flight paths) of murres toward and away from persistent hot spots of capelin were obvious at sea, and murres either diving or sitting on the water with fish in their bills consistently marked capelin schools within hot spots. These flyways and aggregations of sitting birds provided opportunities to use local enhancement to determine the locations of both hot spots of capelin and capelin schools within hot spots, respectively. The north-south-oriented commuter routes observed south of Great Island suggested that we did not locate all hot spots available around this colony; however, we did confirm that persistent hot spots of capelin were available and regularly used by murres breeding in Witless Bay. Overall, by quantifying individual- and population-level arrival and departure behavior of murres from colonies in combination with the distribution, abundance, and spatial and temporal persistence of cap- elin aggregations within foraging ranges, we hypothesize that memory and local enhancement are important search strategies during chick rearing, whereas the Information Center Hypothesis (ICH)-type strategy is not.

Although there was no evidence of an ICH-type mechanism for information exchange on foraging locations beyond the visual range of the colony, murres in the splashdown area at Great Island did depart into mixed-species feeding assemblages within visual range. This use of local enhancement may explain why murres spent more time loafing in the splashdown area at Great Island, from which they could cue on the foraging activities of conspecifics and other marine animals within visual range ("information halo," Burger 1997), compared to Funk Island, where feeding assemblages were not observed from the colony. The lack of evidence for an ICH-type mechanism of information exchange at Great Island was not surprising due to the presence of these feeding assemblages within visual range, the colony's proximity to the coast and capelin spawning beaches, and the low percentage (2\%) of murres in returning flocks. Furthermore, the lack of an ICH-type mechanism for information exchange was not surprising at both colonies because persistent aggregations of capelin were available within foraging ranges.

\section{Information center hypothesis (coarse-scale)}

We found no support for the Information Center Hypothesis (Ward and Zahavi 1973), or Information Halo Hypothesis (Burger 1997), as mechanisms of information exchange beyond visual range of seabird colonies. Using information about distant foraging habitats provided by returning flocks at the colony is probably the least accurate search tactic because return trajectories only reflect general directions of foraging sites, and return trajectories are altered under varying wind speeds and directions (Bryant and Furness 1995, Burger 1997, Spear and Ainley 1997, this study). For instance, murres in the present study generally returned to both colonies with a tailwind, which might increase flight efficiency of the more costly return trip when parents carry a fish for their chicks. Furthermore, return trajectories of birds only indicate the direction of the 
a) 6 Aug 2000

— Return (0500 hours)

sman: Return (0900 hours)

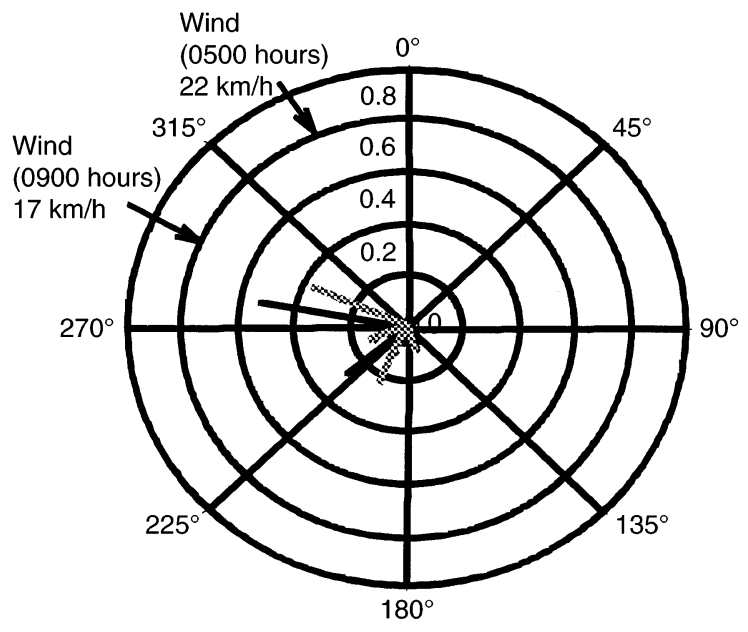

b) 10 Aug 1999

- SD departure (0800 hours)

SD departure (1200 hours)

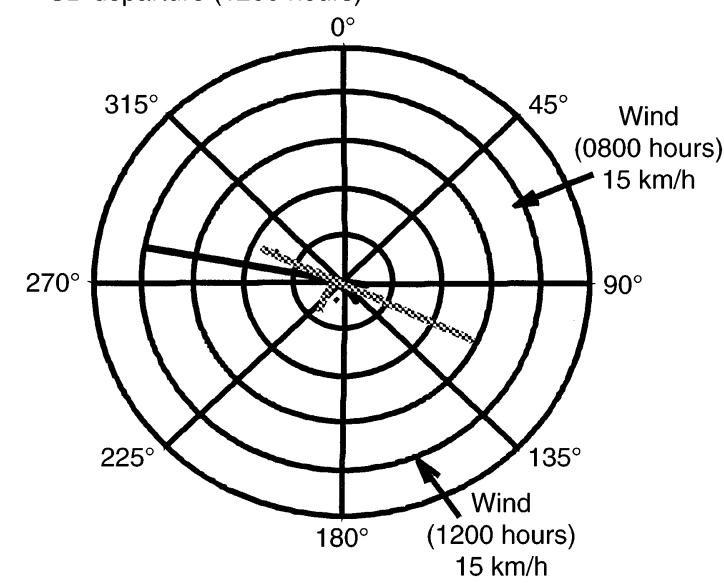

\section{Jul 1998}

- Return (1730 hours)

ansmx Return (2030 hours)

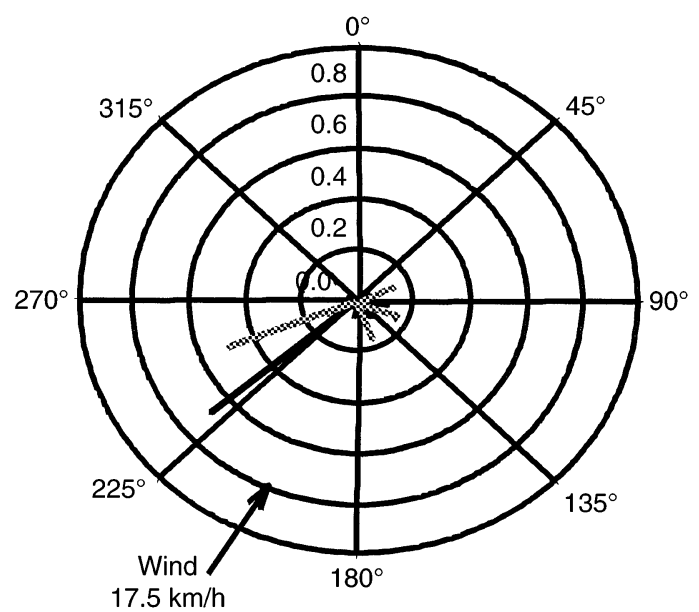

22 Jul 1999

_ SD departure (0530 hours)

SD departure (0830 hours)

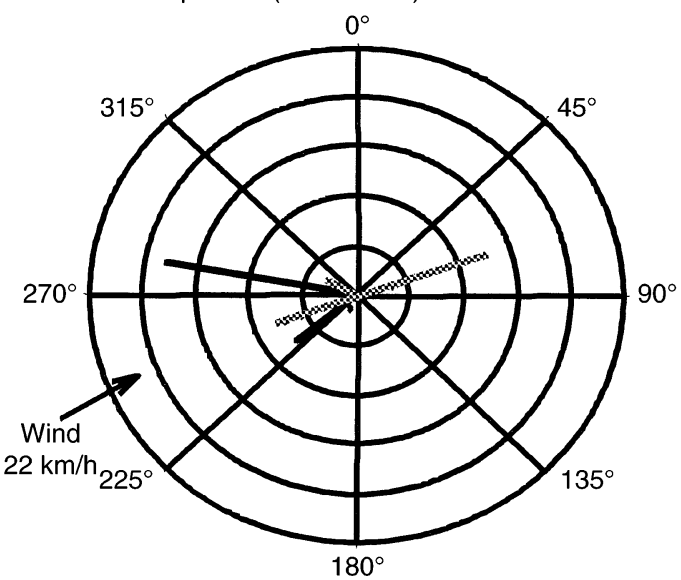

c) 16 Jul 1999

- Direct departure (0530 hours)

Direct departure (0830 hours)

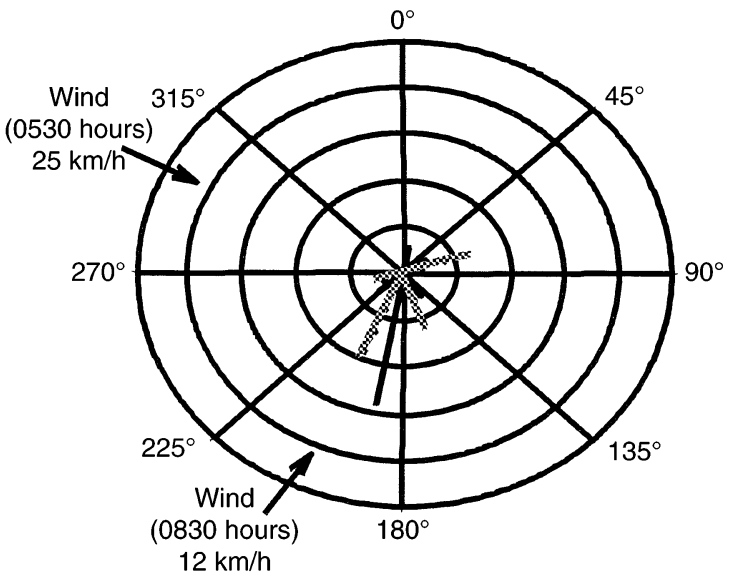




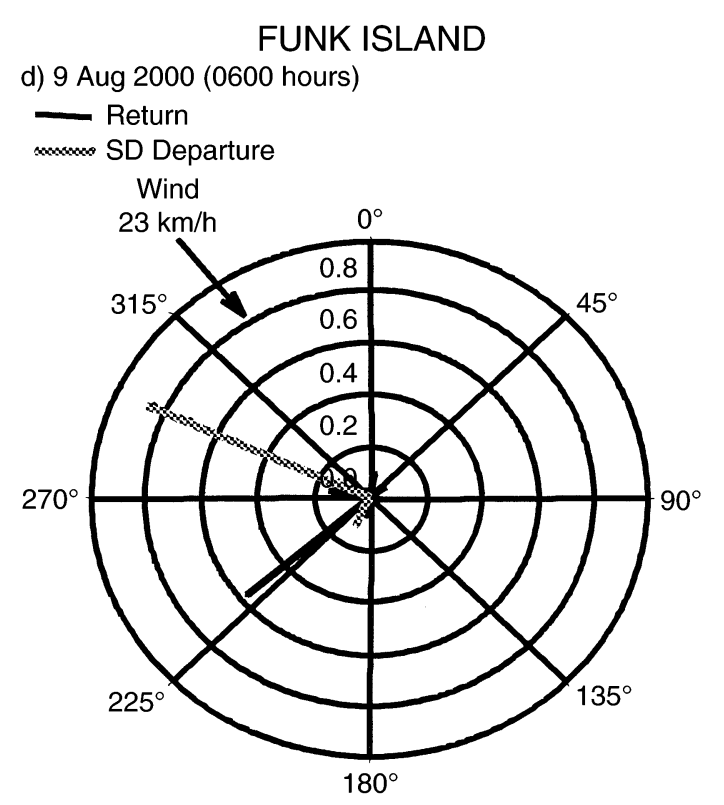

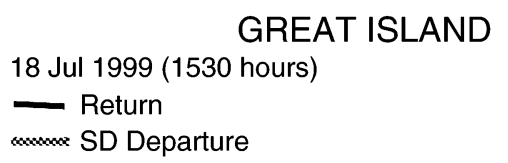

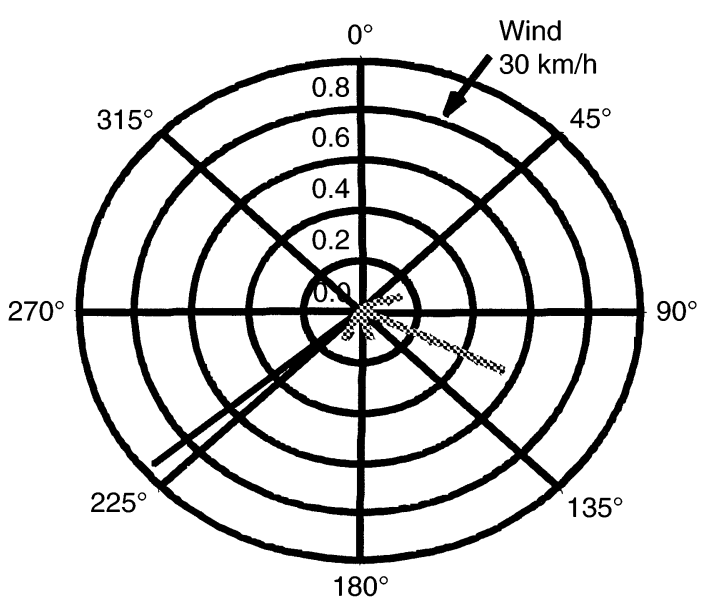

e) 26 Jul 2000 (0730 hours)

- Return

Direct Departure

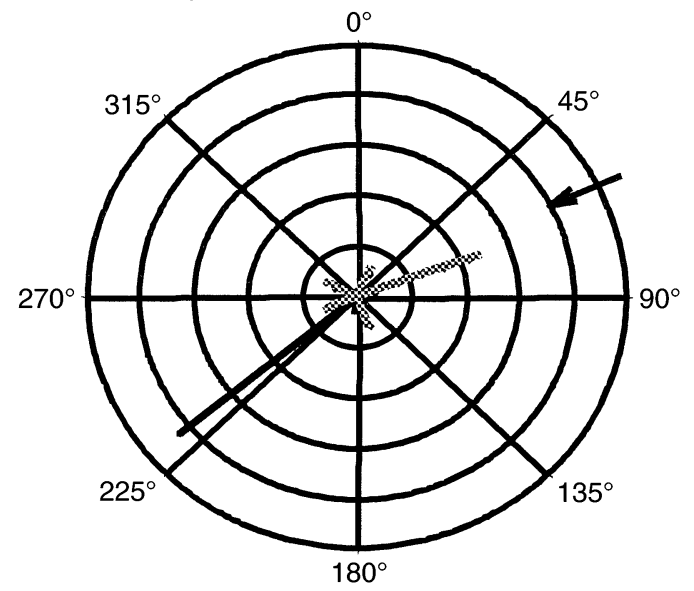

FIg. 4. Continued.

last food patch, when possibly a number are visited on a foraging trip (Wanless et al. 1990, Benoit et al. 1993, Benvenuti et al. 1998). In contrast, the exact location of persistent food patches could be retained in memory, essentially eliminating searching within foraging ranges $(100 \mathrm{~km})$.

\section{Memory (coarse- and fine-scales)}

The successive direct departures of individual murres in similar directions and the consistent use of persistent foraging areas and bypassing of mixed-species feeding assemblages imply the use of memorybased search strategies (Irons 1998). Reducing the time

FIG. 4. Circular plots of departure and return direction of Common Murres (Uria aalge) on Great and Funk Islands, as proportion in each $45^{\circ}$ sector on representative days, illustrating: (a) returns in successive sample periods, (b) splashdown area departures (SD departures) in successive sample periods, (c) departures from nesting ledges (direct departures) in successive sample periods, (d) returns and splashdown area departures in the same sample period, and (e) returns and departures from the nesting ledge in the same sample periods. A shaded bar to the concentric circle labeled " 0.4 " indicates that $40 \%$ of departures or returns occurred from that $45^{\circ}$ sector. The higher the proportion in a sector, the longer is the shaded bar. Wind direction and speed are indicated outside of plots. Dotted and solid lines are offset within each $45^{\circ}$ sector for clarity. 


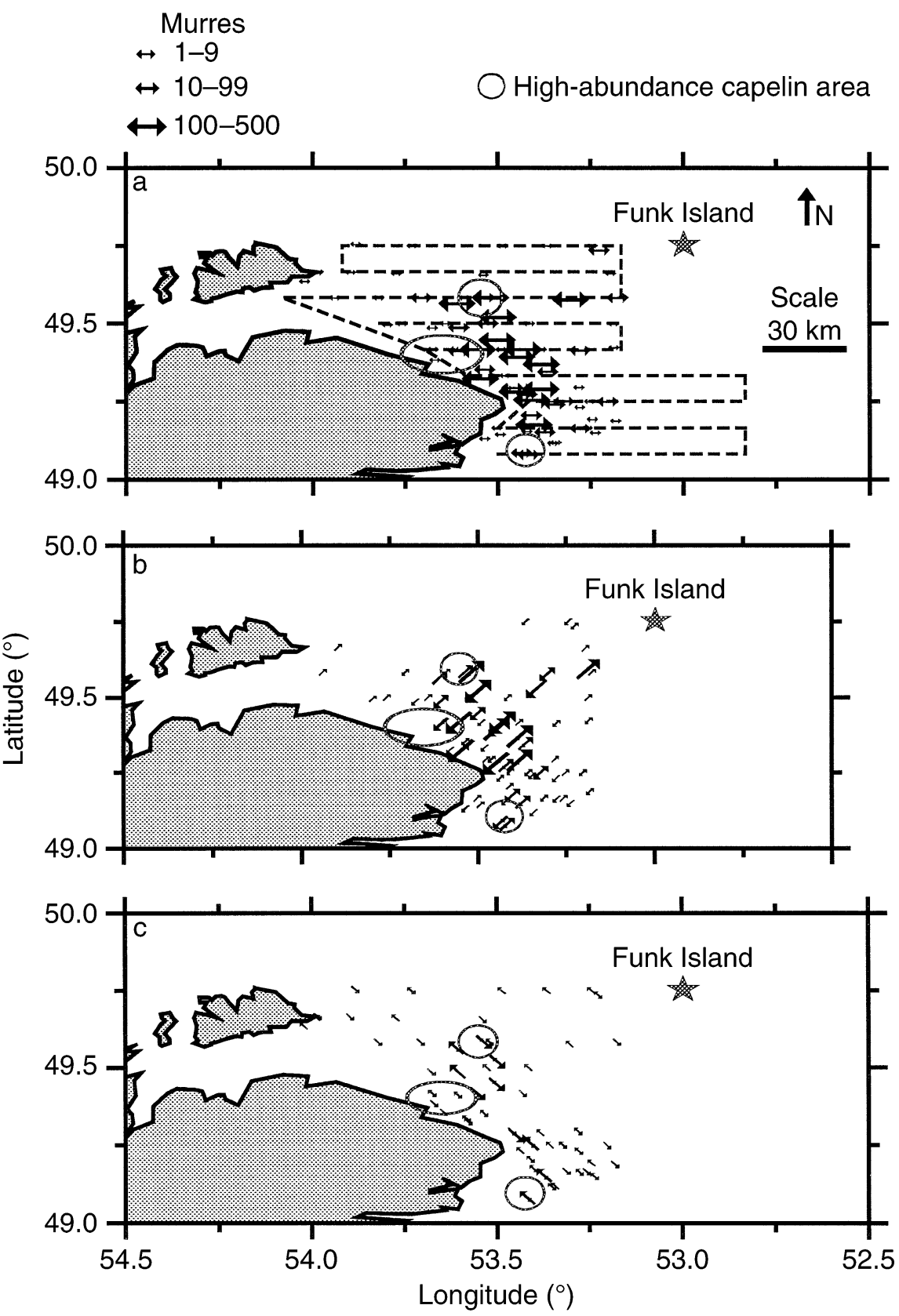

FIG. 5. The distributions and abundances of Common Murres (Uria aalge) flying in (a) all directions, (b) northeast and southwest, and (c) northwest and southeast in 2.25-km bins around Funk Island during the initial survey in 2000. Dashed lines indicate transect routes.

spent searching for prey is important for central-place foragers during breeding when time constraints and energetic demands are high (Cairns et al. 1990). There is much evidence for consistent habitat use by seabirds (Schneider 1991) that suggests that they are capable of constructing and using spatial maps of foraging habitats in a manner similar to birds that cache food (Shettleworth 1990, Smulders 1997). Food-storing birds generally have large hippocampal volumes, a region of the brain essential for spatial learning, relative to non- food-storing birds (Squire 1992). Some seabirds have hippocampal volumes similar to food-storing birds (e.g., Leach's Storm-Petrel, Oceanodroma leucorhoa [Vieillot, 1818]; Abbott et al. 1999), suggesting that they are capable of complex spatial tasks. Murres in other studies have been shown to visit a number of locations during a foraging trip (trapline foraging pattern; Wanless et al. 1990, Benvenuti et al. 1998), which may reflect important exploratory behavior for developing a spatial map of prey distribution and abundance 


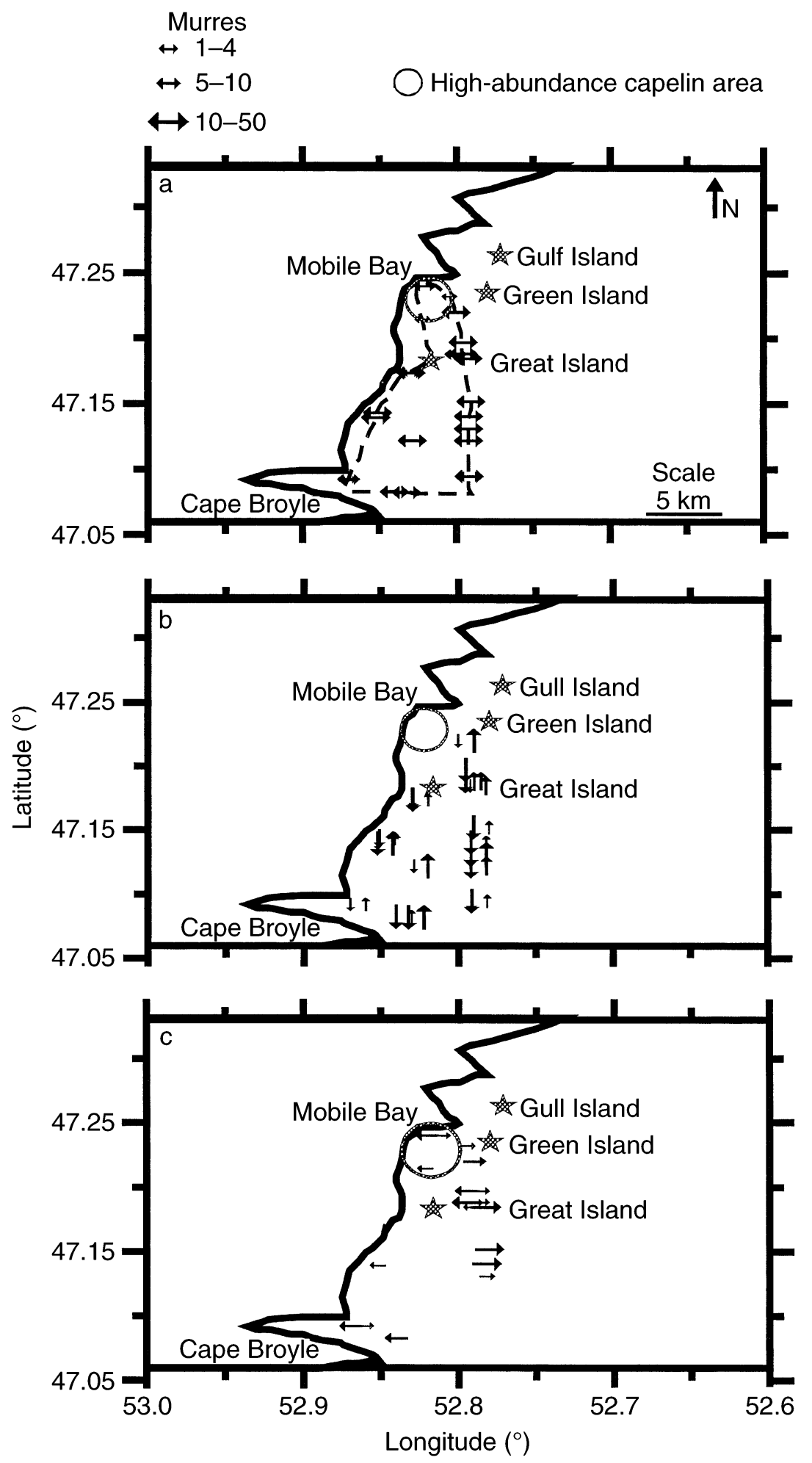

FIG. 6. The distributions and abundances of Common Murres (Uria aalge) flying in all directions, (b) north and south, and (c) east and west in 2.25-km bins around Great Island during the initial survey in 1998. Dashed lines indicate transect routes. 
TABLE 4. Circular correlation coefficients (lower and upper) for the mean angle of wind direction vs. the mean angle of the directions of return flight, departures from splashdown areas, and direct departures for Common Murres (Uria aalge) from Funk Island and Great Island.

\begin{tabular}{|c|c|c|c|c|c|c|}
\hline \multirow{2}{*}{$\begin{array}{c}\text { Foraging } \\
\text { flights, } \\
\text { wind speed }\end{array}$} & \multicolumn{3}{|c|}{ Funk Island } & \multicolumn{3}{|c|}{ Great Island } \\
\hline & Lower & Upper & No. scans & Lower & Upper & No. scans \\
\hline \multicolumn{7}{|c|}{ Wind vs. return } \\
\hline All & 0.0100 & 0.0135 & 76 & 0.0298 & 0.0324 & 104 \\
\hline$<25 \mathrm{~km} / \mathrm{h}$ & 0.0012 & 0.0175 & 48 & NS & NS & 56 \\
\hline$\geq 25 \mathrm{~km} / \mathrm{h}$ & -0.5615 & -0.5442 & 28 & 0.0076 & 0.0180 & 48 \\
\hline \multicolumn{7}{|c|}{ Wind vs. splashdown departure } \\
\hline All & 0.2518 & 0.2584 & 33 & -0.1462 & -0.1403 & 60 \\
\hline$<25 \mathrm{~km} / \mathrm{h}$ & -0.3339 & -0.3193 & 21 & NS & NS & 38 \\
\hline$\geq 25 \mathrm{~km} / \mathrm{h}$ & NS & NS & 12 & -0.9134 & -0.4961 & 22 \\
\hline \multicolumn{7}{|c|}{ Wind vs. direct departure } \\
\hline All & $\ldots$ & $\ldots$ & $\ldots$ & 0.1026 & 0.1110 & 45 \\
\hline$<25 \mathrm{~km} / \mathrm{h}$ & $\ldots$ & $\ldots$ & $\ldots$ & 0.7452 & 0.7642 & 28 \\
\hline$\geq 25 \mathrm{~km} / \mathrm{h}$ & $\ldots$ & $\ldots$ & $\ldots$ & 0.3286 & 0.6865 & 17 \\
\hline
\end{tabular}

Notes: All data were significantly correlated $(\alpha=0.05)$ unless otherwise indicated as nonsignificant (NS). Scans are the number of $360^{\circ}$ scans and departure scans. See Methods for further explanation. Data are combined from all years.

around the colony (Warburton 1990, Mackney and Hughes 1995).

It is possible that murres could rely exclusively on memory to return to the persistent hot spots and capelin schools observed in this study (e.g., Areas 1 and 3, Funk Island). In general, as foragers gain experience in a particular foraging habitat, they will likely remain there (Rissing 1981, Werner et al. 1981). Continuously returning to the same area would be reinforced under continuing high prey abundance but would be extinguished after a number of visits to the area when prey abundance had decreased (win, stay; lose, shift; Kamil 1983), unless birds had a tendency to regularly return to this area regardless of prey abundance (i.e., perseveration; Pinel 1997). Only after this behavior had been extinguished would birds switch to other search tactics. The abundance of murres at persistent capelin hot spots, however, was highly variable in this study and others (e.g., Cairns and Schneider 1990), suggesting that murres may visit a number of foraging habitats (e.g., Wanless et al. 1990, Benvenuti et al. 1998) and/ or use a combination of search strategies (Cairns and Schneider 1990). Little is known about the resolution of seabird cognitive maps and seabirds could use different tactics when searching at varying spatial and temporal scales (Russell et al. 1992).

\section{Local enhancement (coarse- and fine-scales)}

Even though most murres departed both colonies singly (81-94\%) and departure directions of individuals within a scan period were generally random, constant streams of birds flying to and from hot spots along specific commuter routes and high densities of murres consistently sitting near capelin schools within hot spots resulted in capelin aggregations being marked at sea on both coarse- and fine-scales. Therefore, local- ized information transfer on the location of both hot spots and capelin schools within hot spots could operate through local enhancement. Even if hot spots are located based on memory, local enhancement could be important where capelin schools are ephemeral (e.g., Area 2, Funk Island; Cairns and Schneider 1990, Hedd et al. 2001). In fact, a mixed strategy of memory and local enhancement could be essential depending on the resolution of spatial maps and perceptual constraints of murres.

Despite the benefits of local enhancement, this search tactic may not always be preferentially used to locate prey. In the case of mixed-species feeding assemblages, the exact location of a food patch is provided but competition among members can be high (Hoffman et al. 1981, Shealer and Burger 1993, Mills 1998). Seabirds have been observed bypassing such assemblages on their way to more distant foraging habitats (e.g., Hunt and Harrison 1990, Irons 1998), as was observed for murres that successively directly departed Great Island in similar directions during this study. This behavior could reflect an urgency to return to an ephemeral food patch before it moved or before competitors concentrated there. Increased travel times to patches where an individual could forage in less crowded conditions could offset decreased prey capture rates at a nearer feeding assemblage due to increased interference among group members (Obst et al. 1995, Gremillet 1997). Even though murres departing the splashdown area at Great Island landed at mixed-species feeding assemblages to a greater extent than those directly departing nesting ledges, only $10 \%$ of these individuals actually landed at feeding flocks. Birds that carry fish in their bills for delivery to their chicks tend to be the focus of kleptoparasitic attacks by gulls at feeding flocks (Hoffman et al. 1981) and, thus, parents may 
avoid collecting prey in such assemblages when provisioning young (Davoren and Burger 1999). In contrast, murres that fed almost exclusively with conspecifics within hot spots often were observed with fish in their bills, were uniformly spaced at fine spatial scales $(300 \mathrm{~m})$ and aggressive interactions were not observed (Davoren 2001). The lack of food-stealing in these areas may provide an appropriate environment to collect food for chicks.

\section{Conclusions}

Understanding how marine animals locate prey at sea under varying foraging conditions is key to our knowledge of how predator populations will respond to changes in prey populations (Veit 1999). Evidence of Information Center Hypothesis-type information exchange at seabird colonies remains elusive (Bayer 1982, Mock et al. 1988). The information provided by returning flocks of birds, however, was consistent with the direction of the main capelin hot spots and, thus, could act as "insurance" when food conditions change (Ward and Zahavi 1973, Greene 1987, Summers and Feare 1995, Zahavi 1995, Burger 1997). In addition, even though mixed-species feeding assemblages were not used to a great extent, they could also be important in reducing the variation in food intake, thereby minimizing the risk of starvation under poor foraging conditions (Clark and Mangel 1984, 1986, Eckman and Hake 1988). The absence of such social foraging techniques is generally associated with increased time and energy spent foraging (e.g., Davoren 2000). Consequently, the lack of mixed-species feeding assemblages within visual range of Funk Island along with the longer distances to persistent foraging sites relative to Great Island could have reduced the foraging efficiency of murres breeding at Funk Island. This could explain the reduced provisioning rates, breeding success and condition of fledglings at Funk Island compared to Great Island (Davoren and Montevecchi 2003).

The temporal rate of change of locations and abundances of prey aggregations likely shapes search strategies throughout the lifetime of an individual. Oceanographic circulation, such as convergence zones, combined with strong bathymetric relief, or specific habitat requirements of prey, often result in aggregations of seabird prey that are spatially persistent among years (see Schneider 1991). Throughout a lifetime in a specific region (e.g., area surrounding a colony), seabirds could learn the locations of a suite of foraging sites. Regular sampling of these sites would allow daily choice of foraging sites based on recent experience (D. C. Schneider, personal communication) and could lead to the long-term use of traditional feeding grounds in the vicinity of a colony through generations ("hinterland," Cairns 1989). Transgenerational feeding grounds, however, are contingent on similar prey behavior among years. Throughout the 1990s, capelin biology and behavior changed dramatically (Carscadden and Nakashima 1997) and, thus, we propose that the feeding grounds identified in this study may have been relevant to murres only since the early 1990s.

Animals likely use different techniques to locate prey depending on the spatial and temporal resolution at which they are searching (Russell et al. 1992, Noda et al. 1994, Prevot-Julliard and Lebreton 1999, Fauchald et al. 2000). In this study, the combined behavior of predators and prey was consistent with the use of memory, local enhancement, or a mixed strategy of both search tactics by predators to locate prey within foraging ranges of colonies, on both coarse $(1-100 \mathrm{~km})$ and fine (1-1000 m) scales. Such behavioral flexibility is important and reveals that these marine predators may be capable of altering strategies in response to changing prey conditions. How these mechanisms are combined into various strategies will depend on the behavioral and energetic constraints of predators and prey.

\section{ACKNOWLEDGMENTS}

We gratefully acknowledge Arnold Murphy for directing, operating and managing all technical equipment and electronic data aboard the Shamook and for his insightful technical and scientific support. We thank Sarah Jamieson, Janet Russell, Dave Fifield, Laura Dominguez, Chantelle Burke, Euguene MacDonald, and Stefan Garthe for assistance with field work. Special thanks also to the crews of the Canadian Coast Guard Vessel Shamook, the Molly Bawn (Skipper Tommy Reddick), and the Lady Easton II (Skipper Larry Easton), Dave Sencial, and Becky Sjare for providing logistical support in the field and equipment and software. Thanks also to David Schneider for careful early reviews of this manuscript. We also acknowledge the Newfoundland and Labrador Department of Tourism, Culture, and Recreation for the Scientific Access Permits to Great and Funk Island Ecological Reserves and the permit from Canadian Wildlife Service to work with the birds. Funding was provided by NSERC postgraduate scholarship to G. K. Davoren, NSERC Operating Grant to W. A. Montevecchi, DFO vessel support to J. T. Anderson, Mountain Equipment Co-op, Royal Bank Marine Studies Fund, The National Chapter of Canada IODE, Orville Erickson Memorial Fund, and Canadian Federation of University Women.

\section{Literature Cited}

Abbott, M. L., C. J. Walsh, A. E. Storey, I. J. Stenhouse, and C. W. Harley. 1999. Hippocampal volume is related to complexity of nesting habitat in Leach's storm-petrel, a nocturnal procellariiform seabird. Brain, Behavior and Evolution 53:271-276.

Andersson, M., R. Gotmark, and C. G. Wiklund. 1981. Food information in the black-headed gull, Larus ridibundus. Behavioral Ecology and Sociobiology 9:199-202.

Batschelet, E. 1981. Circular statistics in biology. Academic Press, New York, New York, USA.

Bayer, R. D. 1982. How important are bird colonies as information centers? Auk 99:31-40.

Benoit, R., J.-L. DesGranges, and R. McNeil. 1993. Directions of arrival of great blue herons (Ardea herodias) at nests with large chicks near Montreal, Quebec. Canadian Journal of Zoology 71:2250-2257.

Benvenuti, S., F. Bonadonna, and L. G. G. A. Dall'Antonia. 1998. Foraging flights of breeding thick-billed murres (Uria lomvia) as revealed by bird-borne direction recorders. Auk 115:57-66. 
Birkhead, T. R., and D. N. Nettleship. 1980. Census methods for murres Uria spp.: a unified approach, Occasional Paper No. 43. Canadian Wildlife Service, Ottawa, Ontario, Canada.

Bryant, D. M., and R. W. Furness. 1995. Basal metabolic rates of North Atlantic seabirds. Ibis 137:219-226.

Buckley, N. J. 1996. Food finding and the influence of information, local enhancement, and communal roosting on foraging success of North American vultures. Auk 113: 473-488.

Buckley, N. J. 1997. Spatial-concentration effects and the importance of local enhancement in the evolution of colonial breeding in seabirds. American Naturalist 149:10911112.

Burger, A. E. 1997. Arrival and departure behaviour of common murres at colonies: evidence for an information halo? Colonial Waterbirds 20:55-65.

Burger, A. E., and J. F. Piatt. 1990. Flexible time budgets in breeding common murres: buffers against variable prey abundance. Studies in Avian Biology 14:71-83.

Cairns, D. K. 1989. The regulation of seabird colony size: a hinterland model. American Naturalist 134:141-146.

Cairns, D. K., K. A. Bredin, and W. A. Montevecchi. 1987. Activity budgets and foraging ranges of breeding common murres. Auk 104:218-224.

Cairns, D. K., W. A. Montevecchi, V. L. Birt-Friesen, and S. A. Macko. 1990. Energy expenditures, activity budgets, and prey harvest of breeding common murres. Studies in Avian Biology 14:84-92.

Cairns, D. K., W. A. Montevecchi, and W. Threlfall. 1989. Researcher's guide to Newfoundland seabird colonies, Occasional Paper in Biology No. 14. Memorial University of Newfoundland, St. John's, Newfoundland, Canada.

Cairns, D. K., and D. C. Schneider. 1990. Hot spots in cold water: feeding habitat selection by thick-billed murres. Studies in Avian Biology 14:52-60.

Carscadden, J. E., and B. S. Nakashima. 1997. Abundance and changes in distribution, biology and behavior of capelin in response to cooler waters of the 1990s. Pages 457-468 in Forage fishes in marine ecosystems. Alaska Sea Grant College Program Report 97-01, University of Fairbanks, Fairbanks, Alaska, USA.

Clark, C. W., and M. Mangel. 1984. Foraging and flock strategies: information in an uncertain environment. American Naturalist 123:626-641.

Clark, C. W., and M. Mangel. 1986. The evolutionary advantages of group foraging. Theoretical Population Biology 30:45-75.

Clode, D. 1993. Colonially breeding seabirds: predators or prey? Trends in Ecology and Evolution 8:336-338.

Davoren, G. K. 2000. Variability in foraging in response to changing prey distributions in rhinoceros auklets. Marine Ecology Progress Series 198:283-291.

Davoren, G. K. 2001. Predator-prey interactions of common murres (Uria aalge) and fish in the Northwest Atlantic: foraging strategies on multiple scales. Dissertation. Memorial University of Newfoundland, St. John's, Newfoundland, Canada.

Davoren, G. K., and A. E. Burger. 1999. Differences in prey selection and behaviour during self-feeding and chick provisioning in rhinoceros auklets. Animal Behaviour 58:853863.

Davoren, G. K., and W. A. Montevecchi. 2003. Consequences of foraging trip duration on provisioning behaviour and fledging condition of common murres. Journal of Avian Biology 34:44-53.

Davoren, G. K., and W. A. Montevecchi. In press. Signals from seabirds indicate changing biology of capelin sticks. Marine Ecology Progress Series.
Eckman, J., and M. Hake. 1988. Avian flocking reduces starvation risk: an experimental demonstration. Behavioral Ecology and Sociobiology 22:91-94.

Evans, R. M. 1983. Do secondary roosts function as information centers in black-billed gulls? Wilson Bulletin 95: 461-462.

Fauchald, P., K. E. Erikstad, and H. Skarsfjord. 2000. Scaledependent predator-prey interactions: the hierarchical spatial distribution of seabirds and prey. Ecology 81:773-783.

Flemming, S. P. 1990. Making sense of information. Nature 348:291.

Gaston, A. J., and D. N. Nettleship. 1981. The thick-billed murres of Prince Leopold Island: a study of the breeding ecology of a colonial high arctic seabird. Monograph Series No. 6. Canadian Wildlife Service, Ottawa, Ontario, Canada. Greene, E. 1987. Individuals in an osprey colony discriminate between high and low quality information. Nature 329: 239-241.

Gremillet, D. 1997. Catch per unit effort, foraging efficiency, and parental investment in breeding great cormorants (Phalacrocorax carbo carbo). International Council for Exploration of the Sea (ICES) Journal of Marine Sciences 54: 635-644.

Haney, J. C., K. M. Fristrup, and D. S. Lee. 1992. Geometry of visual recruitment by seabirds to ephemeral foraging flocks. Ornis Scandinavica 23:49-62.

Haury, L. R., J. A. McGowan, and P. H. Wiebe. 1978. Patterns and processes in the time-space scales of plankton distributions. Pages 277-327 in J. H. Steele, editor. Spatial pattern in plankton communities. Plenum Press, New York, New York, USA.

Hedd, A., R. Gales, and N. Brothers. 2001. Foraging strategies of shy albatross Thalassarche cauta breeding at Albatross Island, Tasmania, Australia. Marine Ecology Progress Series 224:267-282.

Hoffman, W., D. Heinemann, and J. A. Wiens. 1981. The ecology of seabird feeding flocks in Alaska. Auk 98:437456.

Hunt, G. L., Jr., and N. M. Harrison. 1990. Foraging habitat and prey taken by least auklets at King Island, Alaska. Marine Ecology Progress Series 65:141-150.

Irons, D. B. 1998. Foraging area fidelity of individual seabirds in relation to tidal cycles and flock feeding. Ecology 79:647-655.

Kamil, A. C. 1983. Optimal foraging theory and the psychology of learning. American Zoology 23:291-302.

Mackney, P. A., and R. N. Hughes. 1995. Foraging behaviour and memory window in sticklebacks. Behaviour 132:12411253.

Marzluff, J. M., B. Heinrich, and C. S. Marzluff. 1996. Raven roosts are mobile information centres. Animal Behaviour 51:89-103.

Methven, D. A., and J. F. Piatt. 1991. Seasonal abundance and vertical distribution of capelin (Mallotus villosus) in relation to water temperature at a coastal site off eastern Newfoundland. ICES Journal of Marine Sciences 48:187193.

Milinski, M. 1994. Long-term memory for food patches and implications for ideal free distributions in sticklebacks. Ecology 75:1150-1156.

Mills, K. L. 1998. Multispecies seabird feeding flocks in the Galapagos Islands. Condor 100:277-285.

Mock, D. W., T. C. Lamey, and D. B. A. Thompson. 1988. Falsifiability and the information centre hypothesis. Ornis Scandinavica 19:231-248.

Monaghan, P., P. Walton, S. Wanless, J. D. Uttley, and M. D. Burns. 1994. Effects of prey abundance on the foraging behaviour, diving efficiency and time allocation of breeding guillemots Uria aalge. Ibis 136:214-222. 
Montevecchi, W. A., and L. M. Tuck. 1987. Newfoundland birds: exploitation, study, conservation. Nuttall Ornithological Club, Cambridge, Massachusetts, USA.

Noda, M., K. Gushima, and S. Kakuda. 1994. Local prey search based on spatial memory and expectation in the planktivorous reef fish, Chromis chrysurus (Pomacentridae). Animal Behaviour 47:1413-1422.

Obst, B. S., R. W. Russell, G. L. Hunt, Jr., Z. A. Eppley, and N. M. Harrison. 1995. Foraging radii and energetics of least auklets (Aethia pusilla) breeding on three Bering Sea islands. Physiological Zoology 68:647-672.

O'Driscoll, R. L., G. A. Rose, and J. T. Anderson. 2002. Counting capelin: a comparison of acoustic density and trawl catchability. ICES Journal of Marine Sciences 59: 1062-1071.

Orians, G. H., and N. E. Pearson. 1979. On the theory of central place foraging. Pages 154-177 in D. J. Horn, R. D. Mitchell, and G. R. Stairs, editors. Analyses of ecological systems. Ohio State University Press, Columbus, Ohio, USA.

Pennycuick, C. J. 1987. Flight of seabirds. Pages 43-62 in J. P. Croxall, editor. Seabirds: feeding ecology and role in marine ecosystems. Cambridge University Press, Cambridge, Massachusetts, USA.

Piatt, J. F. 1990. The aggregative response of common murres and Atlantic puffins to schools of capelin. Studies in Avian Biology 14:36-51.

Pinel, J. P. J. 1997. Biopsychology. Allyn and Bacon, Toronto, Ontario, Canada.

Poysa, H. 1992. Group foraging in patch environments: the importance of coarse-level local enhancement. Ornis Scandinavica 23:159-166.

Prevot-Julliard, A.-C., and J.-D. Lebreton. 1999. Spatial organization of foraging within a black-headed gull Larus ridibundus colony. Ibis 141:140-150.

Pyke, G. H. 1984. Optimal foraging theory: a critical review. Annual Review of Ecology and Systematics 15:523-575.

Rissing, S. W. 1981. Prey preferences in the desert horned lizard: influence of prey foraging method and aggressive behavior. Ecology 62:1031-1040.

Rose, G. A., and W. C. Leggett. 1990. The importance of scale to predator-prey spatial correlations:an example of Atlantic fishes. Ecology 71:33-43.

Russell, R. W., G. L. Hunt, Jr., K. O. Coyle, and R. T. Cooney. 1992. Foraging in a fractal environment: spatial patterns in a marine predator-prey system. Landscape Ecology 7: 195-209.

Ryer, C. H., and B. Olla. 1991. Information transfer and the facilitation and inhibition of feeding in a schooling fish Environmental Biology of Fishes 30:317-323.

Ryer, C. H., and B. Olla. 1992. Social mechanisms facilitating exploitation of spatially variable ephemeral food patches in a pelagic marine fish. Animal Behaviour 44:67-74.

Schneider, D. C. 1989. Identifying the spatial scale of density-dependent interaction of predators with schooling fish in the southern Labrador Current. Journal of Fish Biology 35(A):109-115.

Schneider, D. C. 1991. The role of fluid dynamics in the ecology of marine birds. Oceanography and Marine Biology Annual Review 29:487-521.
Schneider, D. C., R. Pierotti, and W. Threlfall. 1990. Alcid patchiness and flight direction near a colony in eastern Newfoundland. Studies in Avian Biology 14:23-35.

Shealer, D. A., and J. Burger. 1993. Effects of interference competition on the foraging activity of tropical roseate terns. Condor 95:322-329.

Shettleworth, S. J. 1990. Spatial memory in food-storing birds. Philosophical Transactions of the Royal Society of London, Series B, 329:143-151.

Smith, J. P. 1995. Foraging sociability of nesting wading birds (Ciconiiformes) at Lake Okeechobee, Florida. Wilson Bulletin 107:437-451.

Smulders, T. V. 1997. How much memory do tits need? Trends in Ecology and Evolution 12:417-418.

Spear, L. B., and D. G. Ainley. 1997. Flight behaviour of seabirds in relation to wind direction and wing morphology. Ibis 139:221-233.

Squire, L. R. 1992. Memory and the hippocampus: a synthesis from findings with rats, monkeys, and humans. Psychological Review 99:195-231.

Stearns, S. C. 1992. The evolution of life histories. Oxford University Press, New York, New York, USA.

Summers, R. W., and C. J. Feare. 1995. Roost departure by European starlings Sturnus vulgaris: effects of competition and choice of feeding site. Journal of Avian Biology 26: 289-295.

Tasker, M. L., P. Hope Jones, T. Dixon, and B. F. Blake. 1984. Counting seabirds at sea from ships: a review of methods employed and a suggestion for a standardized approach. Auk 101:567-577.

Templeman, W. 1948. The life history of the caplin (Mallotus villosus O. F. Muller) in Newfoundland waters. Bulletin of the Newfoundland Government Laboratory 17:1-151.

Uttley, J. D., P. Walton, P. Monaghan, and G. Austin. 1994. The effects of food abundance on breeding performance and adult time budgets of guillemots Uria aalge. Ibis 136: 205-213.

Veit, R. R. 1999. Behavioural responses by foraging petrels to swarms of Antarctic krill Euphausia superba. Ardea 87: 41-50.

Wanless, S., M. P. Harris, and J. A. Morris. 1990. A comparison of feeding areas used by individual common murres (Uria alge), razorbills (Alca torda) and an Atlantic puffin (Fratercula arctica) during the breeding season. Colonial Waterbirds 13:16-24.

Warburton, K. 1990. The use of landmarks by foraging goldfish. Animal Behaviour 40:500-505.

Ward, P., and A. Zahavi. 1973. The importance of certain assemblages of birds as "information-centres" for foodfinding. Ibis 115:517-534.

Werner, E. E., G. G. Mittelbach, and D. J. Hall. 1981. The role of foraging profitability and experience in habitat use by the bluegill sunfish. Ecology 63:116-125.

Wittenberger, J. F., and G. L. Hunt, Jr. 1985. The adaptive significance of coloniality in birds. Pages 1-77 in D. S. Famer, J. R. King, and K. C. Parkes, editors. Avian biology. Volume 8. Academic Press, Toronto, Ontario, Canada.

Zahavi, A. 1995. The evolution of communal roosts as information centers and the pitfall of group selection: a rejoinder to Richner and Heeb. Behavioral Ecology 7:118119.

Zar, J. H. 1996. Biostatistical analysis. Prentice-Hall, Englewood Cliffs, New Jersey, USA. 